\title{
Direct measurement of anaerobic ammonium oxidation (anammox) and denitrification in intact sediment cores
}

\author{
Mark Trimmer ${ }^{1, *}$, Nils Risgaard-Petersen ${ }^{2}$, Joanna C. Nicholls ${ }^{1}$, Pia Engström ${ }^{3}$ \\ ${ }^{1}$ School of Biological and Chemical Sciences, Queen Mary, University of London, London E1 4NS, UK \\ ${ }^{2}$ Department of Marine Ecology, National Environmental Research Institute, Veijlsøveg 25, 8600 Silkeborg, Denmark \\ ${ }^{3}$ Marine Chemistry, Department of Chemistry, Göteborg University, 41296 Göteborg, Sweden
}

\begin{abstract}
Anammox, i.e. the anaerobic oxidation of $\mathrm{NH}_{4}{ }^{+}$with $\mathrm{NO}_{2}{ }^{-}$to $\mathrm{N}_{2}$, has redefined our understanding of nitrogen cycling in aquatic ecosystems. The isotope pairing technique (IPT) is the dominant tool for quantifying denitrification in intact sediments, but it cannot distinguish anammox from denitrification as sources of $\mathrm{N}_{2}$ and may, where anammox is significant, lead to large errors in the estimate of true $\mathrm{N}_{2}$ production. In a previous study, the IPT was revised in theory and a solution was proposed whereby the parameter $r_{14}$, i.e. the ratio of ${ }^{14} \mathrm{NO}_{3}{ }^{-}$to ${ }^{15} \mathrm{NO}_{3}{ }^{-}$in the $\mathrm{NO}_{3}{ }^{-}$reduction zone is used to correct the IPT in the presence of anammox. We begin by exploring the limitations of the 2 indirect techniques previously proposed for estimating $r_{14}$. The first, based on the contribution of anammox to $\mathrm{N}_{2}$ production (ra) in sediment slurry incubations, underestimates anammox and cannot fully correct the IPT. The second, derived from the production of ${ }^{15} \mathrm{~N}-\mathrm{N}_{2}$ gas as a function of ${ }^{15} \mathrm{NO}_{3}{ }^{-}$ concentration, although valid in sieved sediment, was ineffective in natural intact sediments. In contrast, a newly developed direct technique based on the ${ }^{15} \mathrm{~N}$-labelling of $\mathrm{N}_{2} \mathrm{O}$, corrects the IPT in the presence of significant anammox ( $48 \%$ of $\mathrm{N}_{2}$ formation) in natural sediment and can even distinguish between anammox and denitrification in estuarine sediment with a lower anammox contribution $(21 \%)$. We contrast these findings with sediments where anammox is minimal $(<1 \%)$. The ${ }^{15} \mathrm{~N}-\mathrm{N}_{2} \mathrm{O}$ technique allows denitrification and anammox to be quantified in sediment cores using techniques similar to those already established with the original IPT and, importantly, shows that the contribution of anammox to $\mathrm{N}_{2}$ production is greater than previously measured using slurries.
\end{abstract}

KEY WORDS: Anammox $\cdot$ Denitrification $\cdot$ Sediments $\cdot$ Isotope pairing $\cdot{ }^{15} \mathrm{~N}-\mathrm{N}_{2} \mathrm{O}$ technique Resale or republication not permitted without written consent of the publisher

\section{INTRODUCTION}

The discovery of anammox, i.e. the anaerobic oxidation of $\mathrm{NH}_{4}^{+}$with $\mathrm{NO}_{2}^{-}$to $\mathrm{N}_{2}$, has redefined our understanding of $\mathrm{N}$ cycling in aquatic ecosystems and it has been established that this novel process can contribute significantly to benthic $\mathrm{N}_{2}$ production in marine and estuarine systems (Dalsgaard et al. 2005).

Most sediment anammox rates presented in the literature (Dalsgaard \& Thamdrup 2002, Thamdrup \& Dalsgaard 2002, Trimmer et al. 2003, 2005, RisgaardPetersen et al. 2004a, Rysgaard et al. 2004) are, however, potential rates measured with slurry incubations.
Although the use of anaerobic slurries was essential in discovering anammox in the environment and the data obtained so far has increased our knowledge about both the biogeography and regulation of the anammox process, their use disrupts the natural gradients of substrates and redox in sediments and thereby destroys the chemical microenvironment of the bacteria to be studied. There is, therefore, a need for techniques that can directly quantify both anammox and denitrification in intact sediments. Only measurement of anammox and denitrification in intact sediments will enable us to fully elucidate and understand the cycling of $\mathrm{N}$ in aquatic systems. 
Since its introduction by Nielsen in 1992 , the ${ }^{15} \mathrm{~N}$ isotope pairing technique (IPT) has become one of the most widely used techniques for measuring true $\mathrm{N}_{2}$ production (i.e. $p_{14}$ or ${ }^{14} \mathrm{~N}$ production as it would occur without the addition of ${ }^{15} \mathrm{~N}$ ) in intact aquatic sediments (Steingruber et al. 2001). Furthermore, the IPT calculations, in conjunction with the relative ${ }^{15} \mathrm{~N}$-labelling of the $\mathrm{NO}_{3}{ }^{-}$in the overlying water, can be used to determine the contribution of coupled nitrification/denitrification $\left(\mathrm{D}_{\mathrm{n}}\right)$ and denitrification of water-column derived $\mathrm{NO}_{3}{ }^{-}\left(\mathrm{D}_{\mathrm{w}}\right)$ (Nielsen 1992). The IPT cannot, however, distinguish between anammox and denitrification as sources of $\mathrm{N}_{2}$ production and is, therefore, not applicable for direct quantification of anammox in intact sediments. More seriously though, the presence of anammox violates the central assumptions on which the IPT is built and, as a consequence, the IPT will overestimate true $\mathrm{N}_{2}$ production (RisgaardPetersen et al. 2003). The magnitude of this error is positively correlated with the contribution of anammox to $\mathrm{N}_{2}$ production (ra) and negatively correlated with the ratio between ${ }^{14} \mathrm{NO}_{3}{ }^{-}$and ${ }^{15} \mathrm{NO}_{3}{ }^{-}$undergoing reduction $\left(r_{14}\right)$. Hence, the error imposed by the IPT in estimating true $\mathrm{N}_{2}$ production is more likely to be significant in a coastal environment where $r a$ is high and ambient ${ }^{14} \mathrm{NO}_{3}{ }^{-}$is low, and to increase with increasing concentrations of ${ }^{15} \mathrm{NO}_{3}^{-}$(Dalsgaard et al. 2005). This may constitute a serious problem for the continued use of the IPT and there is, therefore, a need for a revision of this technique.

A recently proposed revision (Risgaard-Petersen et al. 2003, 2004b) to the classical IPT should, in theory, enable more accurate quantification of true $\mathrm{N}_{2}$ production where anammox and denitrification coexist. Moreover, this revision can distinguish between anammox and denitrification as sources of $\mathrm{N}_{2}$. The revised IPT (rIPT) assay is the same as the classical IPT using additions of ${ }^{15} \mathrm{NO}_{3}{ }^{-}$to overlying water of intact sediment cores, although a more complex calculation procedure is applied. Input variables in these revised equations are rates of ${ }^{29} \mathrm{~N}_{2}$ and ${ }^{30} \mathrm{~N}_{2}$ production plus estimates of the ratio between ${ }^{14} \mathrm{NO}_{3}{ }^{-}$and ${ }^{15} \mathrm{NO}_{3}{ }^{-}$undergoing reduction $\left(r_{14}\right)$.

In their original revision to the IPT, RisgaardPetersen et al. (2003) proposed that while ${ }^{29} \mathrm{~N}_{2}$ and ${ }^{30} \mathrm{~N}_{2}$ production could be measured directly, the term $r_{14}$ could only be estimated indirectly and they, in turn, suggested 2 procedures to do this. One procedure is based on the measurement of ${ }^{15} \mathrm{~N}-\mathrm{N}_{2}$ production in ${ }^{15} \mathrm{NO}_{3}{ }^{-}$amended sediment cores, combined with a measurement of the contribution of anammox to total $\mathrm{N}_{2}$ production (ra) estimated from slurry incubations. The other is based on measurement of ${ }^{15} \mathrm{~N}-\mathrm{N}_{2}$ production as a function of increasing ${ }^{15} \mathrm{NO}_{3}{ }^{-}$ concentration.
The aim of the present study was to explore the limits of this methodology and to devise necessary improvements. The study was performed in 2 steps. First, we applied the r-IPT in natural bioturbated sediments and in sediments where the fauna had been removed in order to reduce heterogeneity. Although both of the above procedures for indirectly estimating $r_{14}$ could potentially quantify true $p_{14}$ in these sediments, they encountered problems in the natural bioturbated sediments. We then devised a technique for directly measuring $r_{14}$ and thereby more accurately quantifying true $\mathrm{N}_{2}$ production from both anammox and denitrification in heterogeneous and more homogenous intact sediments. This technique is based on the assumption that denitrification, but not anammox, will produce ${ }^{15} \mathrm{~N}-\mathrm{N}_{2} \mathrm{O}$ in a ${ }^{15} \mathrm{NO}_{3}{ }^{-}$sediment core experiment and that the isotopic composition of the ${ }^{15} \mathrm{~N}-\mathrm{N}_{2} \mathrm{O}\left(p^{44} \mathrm{~N}_{2} \mathrm{O}, p^{45} \mathrm{~N}_{2} \mathrm{O}, p^{46} \mathrm{~N}_{2} \mathrm{O}\right)$ will be binomially distributed which, as a consequence, directly reflects the ratio of ${ }^{14} \mathrm{NO}_{3}{ }^{-}$to ${ }^{15} \mathrm{NO}_{3}{ }^{-}$undergoing dissimilatory reduction, i.e. $r_{14}$.

\section{MATERIALS AND METHODS}

Study sites and sampling. This study was conducted using 3 sediment types with a known range of potential anammox activity. Alsbäck, in the deepest part of Gullmarsfjorden (116 m), Sweden (where anammox contributes 30 to $60 \%$ of $\mathrm{N}_{2}$ production) and 2 sites, Gravesend and Southend, in the Thames Estuary, England (where anammox contributes about 5 and $<1 \%$ of $\mathrm{N}_{2}$ production, respectively) (Trimmer et al. 2003, Engström et al. 2005). At Alsbäck, the bottom water has a salinity of ca. 34 and a temperature of $6^{\circ} \mathrm{C}$. The sediment is muddy with a porosity of $0.86(\mathrm{v} / \mathrm{v})$. Sediment was collected from Alsbäck using an Olausen boxcorer followed by direct sampling of subcores in $300 \mathrm{~mm}$ long Plexiglas tubes (inner diameter $55 \mathrm{~mm}$ ). The cores were placed in an insulated box until their return to the laboratory. Another batch of surface sediment (top $2 \mathrm{~cm}$ ) from the box cores was collected, sieved $(1 \mathrm{~mm})$ to remove macrofauna, and transferred to a plastic container ( 500 l, $12 \mathrm{~cm}$ sediment depth). This reconstituted sediment was then preincubated for $3 \mathrm{wk}$ in a dark room at $8^{\circ} \mathrm{C}$ under a laminar flow of seawater to re-establish redox and substrate gradients. Prior to the ${ }^{15} \mathrm{~N}$ incubations, intact sediment subcores were sampled in Plexiglas tubes as mentioned above.

Intact sediment cores were collected at low tide from the intertidal flats at Gravesend and Southend using Plexiglas tubes and bungs and returned to the laboratory within $2 \mathrm{~h}$ as described by Trimmer et al. (2000). At Gravesend the sediments are very fine sands with relatively high organic matter $(2.7 \%$ dry weight) and 
a porosity of 0.67 (Trimmer et al. 2003). At Southend the sediments are fine sands with low organic matter $(<0.5 \%$ dry $\mathrm{wt}$ ) and porosity of 0.5 (Trimmer et al. 2003). Seawater (salinity 30) with 80 to $100 \mathrm{\mu M} \mathrm{NO}_{3}{ }^{-}$ was collected from Southend at high tide for toppingup and storing the cores. For the sediment cores collected from Gravesend (salinity 17, ambient $\mathrm{NO}_{3}{ }^{-}$ $200 \mu \mathrm{M})$, the Southend seawater was diluted with distilled water and enriched with ${ }^{14} \mathrm{NO}_{3}{ }^{-}$. All cores were stored in an aerated barrel of respective water overnight at a constant $16^{\circ} \mathrm{C}$.

Measuring anammox and denitrification potentials in sediment slurries. A standard procedure was used at all sites to measure anammox and denitrification potentials as described in Engström et al. (2005) and Trimmer et al. (2003). Briefly, this consists of screening preincubated anaerobic sediment for anammox activity using ${ }^{15} \mathrm{NH}_{4}{ }^{+}$and ${ }^{14} \mathrm{NO}_{3}{ }^{-}$; the production of ${ }^{29} \mathrm{~N}_{2}$, measured by mass spectrometry, is taken as positive proof of anammox activity. The potential contribution to $\mathrm{N}_{2}$ formation of either anammox or denitrification is calculated from the measured production of ${ }^{29} \mathrm{~N}_{2}$ and ${ }^{30} \mathrm{~N}_{2}$ following enrichment and incubation with 50 to $100 \mu \mathrm{M}^{15} \mathrm{NO}_{3}^{-}$(Thamdrup \& Dalsgaard 2002).

Measuring anammox and denitrification in intact sediment cores. In Alsbäck, the natural and sieved sediment cores were placed in groups of 8 into 4 aerated aquaria of site water (Risgaard-Petersen \& Rysgaard 1995). The 4 aquaria were then amended with ${ }^{15} \mathrm{NO}_{3}{ }^{-}$ (113 $\mathrm{mM} \mathrm{Na}^{15} \mathrm{NO}_{3}\left[99.3{ }^{15} \mathrm{~N}\right.$ at. \%] Sigma-Aldrich) to approximately 50,100, 150 and $200 \mu \mathrm{M}$. The water column in each core was stirred by small magnets driven by a large external rotating magnet, and the cores were preincubated for $24 \mathrm{~h}$. Water samples $(10 \mathrm{ml})$ were collected before and after the addition of ${ }^{15} \mathrm{NO}_{3}{ }^{-}$ and frozen for later determination of the ${ }^{15} \mathrm{~N}$-labelling of the $\mathrm{NO}_{3}{ }^{-}$pool (Dalsgaard et al. 2000).

We then sacrificed 3 of the cores (time zero, $t_{0}$ ) from each aquarium and slurrified these by gently mixing the sediment and overlying water with a Plexiglas rod. A slurry sample $(20 \mathrm{ml})$ was carefully drawn off, allowed to overflow into gas-tight vials (Exetainer, 12 $\mathrm{ml})$, fixed using formaldehyde solution $(100 \mu \mathrm{l}, 38 \%$ $\mathrm{w} / \mathrm{v}$ ), and sealed for later ${ }^{15} \mathrm{~N}-\mathrm{N}_{2}$ analysis. For $\mathrm{N}_{2} \mathrm{O}$ analysis, a larger sample of slurry $(60 \mathrm{ml})$ was taken using a syringe and gently transferred to a serum bottle $(125 \mathrm{ml})$, which was then sealed and crimped. The serum bottle was shaken vigorously by hand for $2 \mathrm{~min}$ and then connected via butyl tubing with a needle on either end to an inverted smaller serum bottle $(55 \mathrm{ml})$ filled with water. The headspace in the larger bottle was then transferred to the smaller bottle by displacing the gas in the large bottle with water introduced by a needle and syringe, while the water in the smaller bottle was displaced by the gas and vented through a nee- dle. The remaining 5 cores (time final, $t_{\mathrm{f}}$ ) in each aquarium were then capped, incubated for a further $24 \mathrm{~h}$ and then treated as $t_{0}$.

${ }^{15} \mathrm{NO}_{3}{ }^{-}$time series experiments with estuarine sediments. The sediment from the Thames is about 10 times more reactive than that at Alsbäck, i.e. a slurry prepared with sediment from the Thames will consume $\mathrm{NO}_{3}{ }^{-}$at a rate of $100 \mathrm{nmol} \mathrm{ml}^{-1} \mathrm{~h}^{-1}$, compared to $<10 \mathrm{nmol} \mathrm{ml}^{-1} \mathrm{~h}^{-1}$ at Alsbäck (Trimmer et al. 2003, Engström et al. 2005). It was, therefore, unnecessary to have a $24 \mathrm{~h}$ preincubation period or to collect such a large gas sample for $\mathrm{N}_{2} \mathrm{O}$ analysis (see later subsection). Oxygen penetrates to $2-4 \mathrm{~mm}$ into the sediment at Southend (Trimmer unpubl. data) and, with a porosity of 0.5 and at $16^{\circ} \mathrm{C}$ it should, in theory, take a spike of ${ }^{15} \mathrm{NO}_{3}{ }^{-}$between 0.9 and $3.4 \mathrm{~h}$ to diffuse to the $\mathrm{NO}_{3}{ }^{-}$reduction zone. To check that our 50 min preincubation was sufficient for ${ }^{15} \mathrm{NO}_{3}{ }^{-}$to fully mix with ${ }^{14} \mathrm{NO}_{3}{ }^{-}$in the reduction zone, and that ${ }^{15} \mathrm{~N}$-labelling remained constant with time, a single time series experiment was performed at Southend. After overnight storage the sediment cores were transferred to a single holding tank and just the overlying water in 32 cores was enriched to about $30 \%{ }^{15} \mathrm{~N}$, i.e. $50 \mu \mathrm{M}^{15} \mathrm{NO}_{3}{ }^{-}(50 \mu \mathrm{l}$ of 113 $\mathrm{mM} \mathrm{Na}{ }^{15} \mathrm{NO}_{3}\left[99.3{ }^{15} \mathrm{~N}\right.$ at. \%] Sigma-Aldrich); 4 cores were left unamended as references. The overlying water was then gently mixed and the cores preincubated for $50 \mathrm{~min}$. After this preincubation period a water sample $(5 \mathrm{ml})$ was collected from each core, filtered $\left(0.2 \mu \mathrm{m}\right.$ Minisart Plus ${ }^{\mathrm{TM}}$, Sartorius) and frozen at $-20^{\circ} \mathrm{C}$ until later analysis. We immediately sacrificed 3 cores $\left(t_{0}\right)$ and treated them as those at Alsbäck, but 2 equalvolume slurry samples $(20 \mathrm{ml})$ were carefully drawn off into gas-tight vials (as in preceding subsection) for later ${ }^{15} \mathrm{~N}-\mathrm{N}_{2}$ and $\mathrm{N}_{2} \mathrm{O}$ gas analyses. The remainder of the ${ }^{15} \mathrm{NO}_{3}{ }^{-}$enriched cores were then sealed and incubated in the dark at $16^{\circ} \mathrm{C}$ with gentle stirring ( 60 rpm) of the water column, and sacrificed in batches of 3 every hour for $6 \mathrm{~h}$. The 4 reference cores were processed in the same way as the ${ }^{15} \mathrm{NO}_{3}{ }^{-}$enriched cores.

${ }^{15} \mathrm{NO}_{3}{ }^{-}$concentration series experiment with estuarine sediments. Concentrations of ambient ${ }^{14} \mathrm{NO}_{3}{ }^{-}$are much higher in the water of the Thames estuary (100 to $600 \mu \mathrm{M})$ than Alsbäck $(<10 \mu \mathrm{M})$. Hence, $r_{14}$ is relatively high and, in the former, with the lower contribution of anammox to $\mathrm{N}_{2}$ production in the Thames estuary ( $\mathrm{ra}$ slurries $<10 \%$ ), any potential dependency between $p_{14}$ and ${ }^{15} \mathrm{NO}_{3}{ }^{-}$as a result of anammox is harder to detect. Therefore, to measure any effect of anammox on the estimate of $p_{14}$ with the original IPT in the Thames, the design of the ${ }^{15} \mathrm{NO}_{3}{ }^{-}$concentration series experiment was changed to increase the sensitivity. Cores were collected (as in the preceding paragraph for time) and the overlying water in 32 sediment cores from each site was enriched incrementally with ${ }^{15} \mathrm{NO}_{3}{ }^{-}$(7 to $224 \mu \mathrm{M}$ 
for Southend, 15 to $448 \mu \mathrm{M}$ for Gravesend), i.e. $\mathrm{n}=32$; $\mathrm{df}=30$ for linear regression. The cores were then preincubated for $50 \mathrm{~min}$, capped, run for 3 to $4 \mathrm{~h}$, and then treated as described above, with 4 unamended cores as references.

${ }^{15} \mathrm{~N}-\mathbf{N}_{2}$ and $\mathbf{N}_{2} \mathbf{O}$ gas analyses. For $\mathrm{N}_{2}$ analysis a headspace ( $2 \mathrm{ml}$ analytical grade $\mathrm{He}$ ) was introduced into the gas-tight vials using a 2-way valve and a syringe. The vials were then shaken vigorously, inverted, and stored upright at $22^{\circ} \mathrm{C}$ to allow $\mathrm{N}_{2}$ to equilibrate between the water phase and headspace. Samples of the headspace $(50 \mu \mathrm{l})$ were then injected using an auto-sampler into an elemental analyser but bypassing the reduction/oxidation columns, so that ${ }^{15} \mathrm{~N}$-labelled $\mathrm{N}_{2} \mathrm{O}$ would not be reduced to ${ }^{15} \mathrm{~N}-\mathrm{N}_{2}$. Gases were separated on the elemental analyser's GC column prior to passing to the continuous-flow isotope ratio mass spectrometer. Calibration was performed with $\mathrm{N}_{2}$ in helium over air-equilibrated water at $22^{\circ} \mathrm{C}$ and the specific mass to charge ratios for $\mathrm{m} / \mathrm{z} \mathrm{28,} 29$ and 30 nitrogen $\left({ }^{28} \mathrm{~N}_{2},{ }^{29} \mathrm{~N}_{2}\right.$ and $\left.{ }^{30} \mathrm{~N}_{2}\right)$ measured (Delta Matt Plus, Thermo-Finnigan). For $\mathrm{N}_{2} \mathrm{O}$ isotope ratio analysis the gas from the $55 \mathrm{ml}$ serum bottles from Alsbäck was swept, using a 2-way needle and analytical grade $\mathrm{He}$, to a trace gas pre-concentrator (Cryo-Focusing, PreCon, Thermo-Finnigan). For the Thames $\mathrm{N}_{2} \mathrm{O}$ analysis, a headspace ( $3 \mathrm{ml}$ analytical grade $\mathrm{He}$ ) was introduced into the gas-tight vials as above. Samples of the headspace $(0.5$ to $1 \mathrm{ml})$ were subsampled using a gas-tight syringe (SGE Gastight Luer Lock syringe) into an empty gas-tight vial for subsequent sweeping via the 2-way needle. The gases were then dried and scrubbed free of most of the $\mathrm{CO}_{2}$ before being cryofocused twice in liquid $\mathrm{N}_{2}$ and final separation of $\mathrm{N}_{2} \mathrm{O}$ from $\mathrm{CO}_{2}$ on a PoraPLOT Q capillary column. The sample was then passed to the continuous-flow isotope ratio mass spectrometer (Finnigan MAT Delta ${ }^{\text {Plus }}$ ) via an interface (ConFlo III Interface, Thermo-Finnigan) and the specific mass to charge ratios for $\mathrm{m} / \mathrm{z} 44,45$ and $46\left({ }^{44} \mathrm{~N}_{2} \mathrm{O},{ }^{45} \mathrm{~N}_{2} \mathrm{O}\right.$ and $\left.{ }^{46} \mathrm{~N}_{2} \mathrm{O}\right)$ were measured. Calibration was performed with known amounts of $\mathrm{N}_{2} \mathrm{O}$ (98 ppm; Scientific and Technical Gases) over the range 0.41 to $13.25 \mathrm{nmol} \mathrm{N}_{2} \mathrm{O}\left(\sum{ }^{44} \mathrm{~N}_{2} \mathrm{O},{ }^{45} \mathrm{~N}_{2} \mathrm{O}\right.$ and ${ }^{46} \mathrm{~N}_{2} \mathrm{O}$ ) and was linear between 0.8 and 99 pmol for ${ }^{45} \mathrm{~N}_{2} \mathrm{O}$ and ${ }^{46} \mathrm{~N}_{2} \mathrm{O}$. Here, for clarity, we refer to ${ }^{15} \mathrm{~N}$ labelled $\mathrm{N}_{2} \mathrm{O}$ as ${ }^{45} \mathrm{~N}_{2} \mathrm{O}$ and ${ }^{46} \mathrm{~N}_{2} \mathrm{O}$, and not as ${ }^{29} \mathrm{~N}_{2}{ }^{16} \mathrm{O}$ and ${ }^{30} \mathrm{~N}_{2}{ }^{16} \mathrm{O}$.

Calculations. We used 2 different procedures to estimate true $\mathrm{N}_{2}$ production $\left(p_{14}\right)$ : the IPT (Nielsen 1992) and the revised IPT proposed by (Risgaard-Petersen et al. 2003). The IPT estimates $\mathrm{N}_{2}$ production as:

$$
p_{14} I P T=\frac{p^{29} N_{2}}{2 \cdot p^{30} N_{2}} \cdot\left(2 \cdot p^{30} N_{2}+p^{29} N_{2}\right)
$$

where $p^{29} \mathrm{~N}_{2}$ and $p^{30} \mathrm{~N}_{2}$ are production rates of ${ }^{29} \mathrm{~N}_{2}$ and
${ }^{30} \mathrm{~N}_{2}$, respectively. The revised IPT estimates total $\mathrm{N}_{2}$ production $\left(\mathrm{N}_{2}\right.$ from both anammox and denitrification) as:

$$
\mathrm{r}-\mathrm{IPT} p_{14}=2 r_{14} \cdot\left(p^{29} \mathrm{~N}_{2}+p^{30} \mathrm{~N}_{2} \cdot\left(1-r_{14}\right)\right)
$$

and anammox ( $\left.p_{14} \mathrm{AAO}\right)$ as

$$
p_{14} A A O=2 r_{14} \cdot\left(p^{29} \mathrm{~N}_{2}-2 \cdot r_{14} \cdot p^{30} \mathrm{~N}_{2}\right)
$$

Denitrification is then estimated as the difference between Eqs. (2) and (3). As above, $p^{29} \mathrm{~N}_{2}$ and $p^{30} \mathrm{~N}_{2}$ are the production of ${ }^{29} \mathrm{~N}_{2}$ and ${ }^{30} \mathrm{~N}_{2}$ after ${ }^{15} \mathrm{NO}_{3}{ }^{-}$amendment and $r_{14}$ is the ratio between ${ }^{14} \mathrm{NO}_{3}{ }^{-}$and ${ }^{15} \mathrm{NO}_{3}{ }^{-}$in the $\mathrm{NO}_{3}{ }^{-}$reduction zone. In Eqs. (1), (2) and (3), $p^{29} \mathrm{~N}_{2}$ and $p^{30} \mathrm{~N}_{2}$ are directly quantifiable using mass spectrometry; the difference being that Eqs. (2) and (3) hinge on the parameter $r_{14}$. Here, 3 different methods were used to estimate $r_{14}$ : firstly 2 indirect methods proposed by (Risgaard-Petersen et al. 2003), and then a third, more direct, method.

Method 1: Here $r_{14}$ is calculated from the contribution of anammox to total $\mathrm{N}_{2}$ production ( $r a$ ) measured in anaerobic slurries and $p^{29} \mathrm{~N}_{2}$ and $p^{30} \mathrm{~N}_{2}$ according to:

$$
r_{14}=\frac{(1-r a) \cdot\left(\frac{p^{29} \mathrm{~N}_{2}}{p^{30} \mathrm{~N}_{2}}\right)-r a}{(2-r a)}
$$

Method 2: Here $r_{14}$ is calculated using $p^{29} \mathrm{~N}_{2}$ and $p^{30} \mathrm{~N}_{2}$ measured in sediment cores amended with a range of ${ }^{15} \mathrm{NO}_{3}{ }^{-}$concentrations according to:

$$
r_{14}{ }^{(1)}=\frac{p^{29} \mathrm{~N}_{2}{ }^{(1)}-V \cdot p^{29} \mathrm{~N}_{2}{ }^{(2)}}{2 \cdot\left(p^{30} \mathrm{~N}_{2}{ }^{(1)}-V^{2} \cdot p^{30} \mathrm{~N}_{2}^{(2)}\right)}
$$

where $p^{29} \mathrm{~N}_{2}{ }^{(1)}$ and $p^{30} \mathrm{~N}_{2}{ }^{(1)}$ are the production of ${ }^{29} \mathrm{~N}_{2}$ and ${ }^{30} \mathrm{~N}_{2}$ in Incubation 1 and $p^{29} \mathrm{~N}_{2}{ }^{(2)}$ and $p^{30} \mathrm{~N}_{2}{ }^{(2)}$ are the production of ${ }^{29} \mathrm{~N}_{2}$ and ${ }^{30} \mathrm{~N}_{2}$ in Incubation 2 - a parallel incubation with different ${ }^{15} \mathrm{NO}_{3}{ }^{-}$concentrations in the overlying water column. $V$ is the ratio between the ${ }^{15} \mathrm{NO}_{3}{ }^{-}$concentration in the water column in Incubations 1 and 2, which can be estimated from the production of ${ }^{15} \mathrm{~N}$ gas in the 2 incubations:

$$
V=\frac{p^{29} \mathrm{~N}_{2}^{(1)}+2 \cdot p^{30} \mathrm{~N}_{2}^{(1)}}{p^{29} \mathrm{~N}_{2}^{(2)}+2 \cdot p^{30} \mathrm{~N}_{2}^{(2)}}
$$

Note that in the paper of Risgaard-Petersen et al. (2003), Eq. (5) is not correct. The correct equation is given in Risgaard-Petersen et al. (2004b).

Method 3: Here $r_{14}$ is estimated from the ${ }^{15} \mathrm{~N}$-labelling of the $\mathrm{N}_{2} \mathrm{O}$ produced during the incubation, i.e. ${ }^{14} \mathrm{~N}^{15} \mathrm{~N}_{2} \mathrm{O}\left(p^{45} \mathrm{~N}_{2} \mathrm{O}\right)$ and ${ }^{15} \mathrm{~N}^{15} \mathrm{~N}_{2} \mathrm{O}\left(p^{46} \mathrm{~N}_{2} \mathrm{O}\right)$. For the purposes of this technique, denitrification is assumed to be the only quantitative significant source of ${ }^{15} \mathrm{~N}$ $\mathrm{N}_{2} \mathrm{O}$ in a ${ }^{15} \mathrm{NO}_{3}{ }^{-}$labelling experiment (see 'Results and Discussion' for full rationale). If the ratio between ${ }^{15} \mathrm{NO}_{3}{ }^{-}$and ${ }^{14} \mathrm{NO}_{3}{ }^{-}$is constant in the $\mathrm{NO}_{3}{ }^{-}$reduction zone, the produced isotopic $\mathrm{N}_{2} \mathrm{O}$ species will be bi- 
nomially distributed (equivalent to the fundamental assumption of the IPT regarding the distribution of ${ }^{15} \mathrm{~N}-\mathrm{N}_{2}$ isotopic species) and the ratio between $p^{45} \mathrm{~N}_{2} \mathrm{O}$ and $p^{46} \mathrm{~N}_{2} \mathrm{O}$ can be expressed as:

$$
\frac{p^{45} \mathrm{~N}_{2} \mathrm{O}}{p^{46} \mathrm{~N}_{2} \mathrm{O}}=\frac{2 \cdot x \cdot y}{y^{2}}=2 \cdot r_{14}
$$

where $x$ and $y$ are the mole fractions of ${ }^{14} \mathrm{NO}_{3}{ }^{-}$and ${ }^{15} \mathrm{NO}_{3}{ }^{-}$, respectively in the $\mathrm{NO}_{3}{ }^{-}$reduction zone (e.g. $\left.x={ }^{14} \mathrm{NO}_{3}^{-} /\left[{ }^{14} \mathrm{NO}_{3}^{-}{ }^{+15} \mathrm{NO}_{3}^{-}\right]\right)$, and $r_{14}$ is the ratio between ${ }^{14} \mathrm{NO}_{3}{ }^{-}$and ${ }^{15} \mathrm{NO}_{3}{ }^{-}$in the $\mathrm{NO}_{3}{ }^{-}$reduction zone. Rearranging Eq. (7), $r_{14}$ can be expressed as

$$
r_{14}=\frac{p^{45} \mathrm{~N}_{2} \mathrm{O}}{2 \cdot p^{46} \mathrm{~N}_{2} \mathrm{O}}
$$

The term $r_{14}$ can be converted into a more familiar parameter which is useful when interpreting these calculations, i.e. $q$. The term $q$ is the proportion of ${ }^{15} \mathrm{~N}$ in the total $\mathrm{N}$ gas pool and is directly related to $r_{14}$ :

$$
q=\frac{1}{r_{14}+1}
$$

Using $q$ enables better statistical analysis of the data, since $q$ is constrained between 0 and 1 , where $r_{14}$ is not and, therefore, the data are better suited to regression analysis. The term $q$ is calculated for both ${ }^{15} \mathrm{~N}$ gas species, i.e. $q \mathrm{~N}_{2}$ vs. $q \mathrm{~N}_{2} \mathrm{O}$, and subjected to regression analysis. If the slope deviates significantly from 1 , then the change in the predicted distribution of ${ }^{15} \mathrm{~N}$ is taken as being due to anammox. To use the $q \mathrm{~N}_{2}$ vs. $q \mathrm{~N}_{2} \mathrm{O}$ slope effectively, it is essential to have a good spread of data, too few replicates or too few ${ }^{15} \mathrm{NO}_{3}{ }^{-}$concentrations, and/or incubations with very low ambient ${ }^{14} \mathrm{NO}_{3}{ }^{-}$ concentrations are likely to give an inaccurate slope. The slope of $q \mathrm{~N}_{2}$ vs. $q \mathrm{~N}_{2} \mathrm{O}$ is directly related to $r a$, i.e. the contribution of anammox to $\mathrm{N}_{2}$ production according to:

$$
\text { ra }=\frac{2-2 \cdot \text { slope }}{2-\text { slope }}
$$

and can be used to illustrate the effects of anammox on the distribution of ${ }^{15} \mathrm{~N}$ in both the $\mathrm{N}_{2}$ and $\mathrm{N}_{2} \mathrm{O}$ pools.

\section{RESULTS AND DISCUSSION}

\section{Evaluation of Methods 1 and 2: indirect quantification of $r_{14}$ from $r a$ and $V$ in a ${ }^{15} \mathrm{NO}_{3}{ }^{-}$concentration series}

According to the data from the slurry incubations in Alsbäck, anammox accounted for 36 and $40 \%$ of total $\mathrm{N}_{2}$ production in the natural and the sieved sediment, respectively, which agreed well with previous measurements for this site (Engström 2004). True $\mathrm{N}_{2}$ production $\left(p_{14}\right)$ estimated with the original IPT was de- pendent on the ${ }^{15} \mathrm{NO}_{3}{ }^{-}$concentration in the water column for both the sieved (Fig. 1A) and the natural (Fig. 1B) sediment. The effect of bioturbation on the accuracy of each estimate of $p_{14}$ was clear from the difference in the errors bars for the respective graphs (Fig. 1). Such a dependency between $p_{14}$ and ${ }^{15} \mathrm{NO}_{3}{ }^{-}$is to be expected, since the IPT includes ${ }^{29} \mathrm{~N}_{2}$ production from anammox in the calculation of ${ }^{14} \mathrm{~N}-\mathrm{N}_{2}$ production $\left(p_{14}\right)$ and this production represents an additional oxidation of ${ }^{14} \mathrm{NH}_{4}{ }^{+}$, which would not have taken place in the absence of ${ }^{15} \mathrm{NO}_{3}{ }^{-}$addition (Risgaard-Petersen et al. 2003). Although using method 1 (ra) in the r-IPT reduced the estimate of $p_{14}$ compared to that estimated with the original IPT, there was still dependency be-
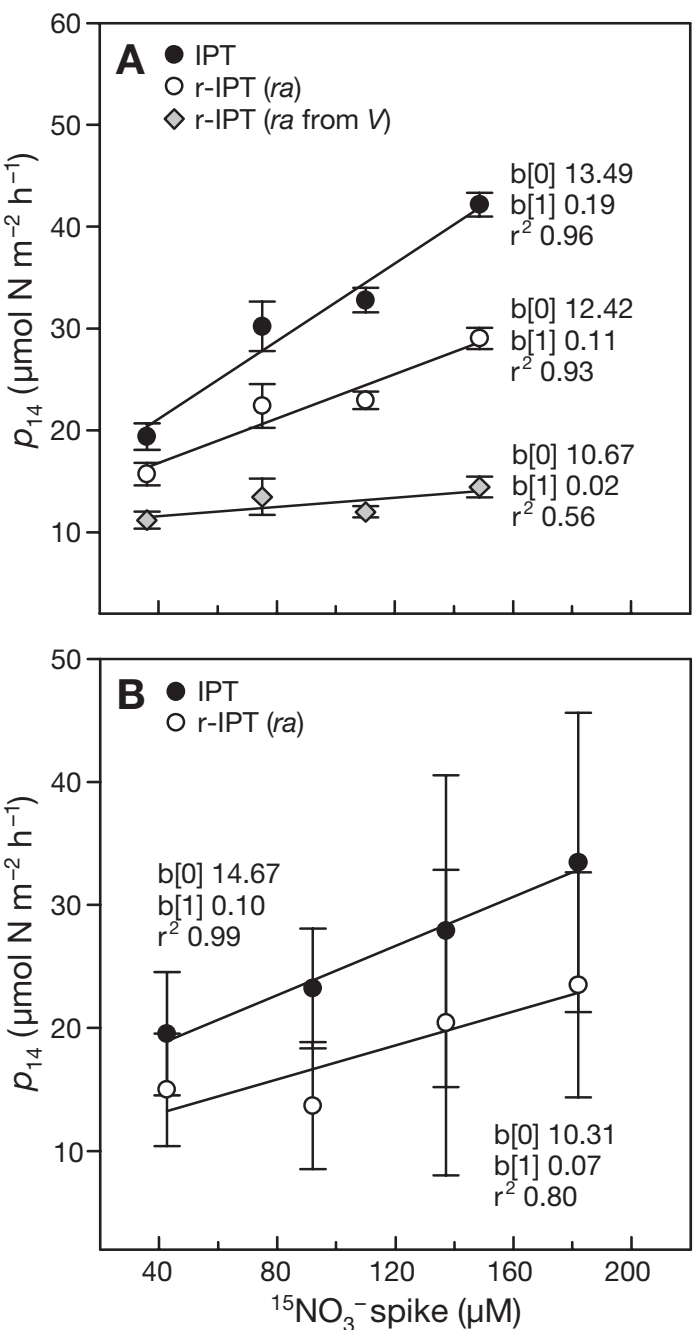

Fig. 1. Estimated (means $\pm 1 \mathrm{SEM} ; \mathrm{n}=5$ ) true production of $\mathrm{N}_{2}$ gas $\left(p_{14}\right)$ in (A) sieved sediment using original isotope pairing technique (IPT) and r-IPT corrected using Method 1 (ra from slurries) and combination of Methods 1 and 2 (ra from $V$ ), and (B) natural sediment from Alsbäck, using original IPT and r-IPT corrected using Method 1 (ra from slurries) only. Regression constants: $b[0]=$ intercept, $b[1]=$ slope. See 'Materials and methods' for parameter details 
tween $p_{14}$ and ${ }^{15} \mathrm{NO}_{3}{ }^{-}$(Fig. 1). Theoretically, however, such a correlation should not be seen, because in Eq. (2) the 'false' ${ }^{29} \mathrm{~N}_{2}$ production from anammox should have been taken into account.

Calculating the r-IPT with Method $2(V)$ produced negative values for $p_{14}$ in the natural sediment (data not shown), probably because of excessive sediment heterogeneity and, whereas this method assumes equal ra for each core, it became clear that ra varied across the cores. In light of this, it was only possible to apply the rIPT with Method 2 to the sieved sediment from Alsbäck and, accordingly, $p_{14}$ ranged from 5 to $22 \mu \mathrm{mol} \mathrm{N} \mathrm{m}{ }^{-2}$ $\mathrm{h}^{-1}$ for all combinations of the different ${ }^{15} \mathrm{NO}_{3}{ }^{-}$concentrations and was, on average, $12.8 \pm 2.2(\mathrm{SEM}) \mu \mathrm{mol} \mathrm{N}$ $\mathrm{m}^{-2} \mathrm{~h}^{-1}$ (data not shown). Anammox ranged from 3.8 to $11 \mu \mathrm{mol} \mathrm{N} \mathrm{m} \mathrm{N}^{-2} \mathrm{~h}^{-1}$, with an average of $7.6 \pm 0.95$ (SEM) umol $\mathrm{N} \mathrm{m}^{-2} \mathrm{~h}^{-1}$, which suggests that anammox accounted for approximately $59 \%$ of $\mathrm{N}_{2}$ production, i.e. somewhat more than inferred from the slurry incubations (see next subsection). Using the ra value of 0.59 derived with Method $2(V)$ as input to Eq. (4) (i.e. Method 1) for estimation of $r_{14}$ for the individual cores, we then recalculated $p_{14}$ for the sieved sediment using the r-IPT (Eq. 2). This resulted in no significant dependency $(\mathrm{p}=0.13)$ between the estimated value of $p_{14}$ and the concentration of ${ }^{15} \mathrm{NO}_{3}{ }^{-}$(Fig. 1A) and is indicative of a valid result (Risgaard-Petersen et al. 2003). This suggests that the slurry method underestimated the actual contribution of anammox to $\mathrm{N}_{2}$ production (ra) and thereby did not fully take into account the 'false' ${ }^{29} \mathrm{~N}_{2}$ production from anammox.

Thus the results from the first half of the study support the use of a ${ }^{15} \mathrm{NO}_{3}{ }^{-}$concentration series experiment to estimate $p_{14}$ from anammox and denitrification in sediments where the processes coexist. This method, however, requires minimal sediment heterogeneity and this criteria was not met in the natural sediment from Alsbäck. To measure true $\mathrm{N}_{2}$ production from both anammox and denitrification in this sediment, and probably in most natural bioturbated sediment, an alternative procedure is required.

\section{Evaluation of Method 3: quantification of $r_{14}$ from the ${ }^{15} \mathrm{~N}$ isotopic signature of $\mathrm{N}_{2} \mathrm{O}$}

If there was no anammox and denitrification was solely responsible for the production of ${ }^{15} \mathrm{~N}-\mathrm{N}_{2}$ and ${ }^{15} \mathrm{~N}-\mathrm{N}_{2} \mathrm{O}$, then it is valid to calculate $r_{14}$ from ${ }^{15} \mathrm{~N}-\mathrm{N}_{2}$, that is:

$$
r_{14}=\frac{p^{29} N_{2}}{2 \cdot p^{30} N_{2}}
$$

(Risgaard-Petersen et al. 2003) and, consequently, $r_{14}$ would be the same regardless of which ${ }^{15} \mathrm{~N}-\mathrm{N}$ gas species it was calculated from. In the presence of anammox, however, $r_{14}$ estimated from ${ }^{29} \mathrm{~N}_{2}$ and ${ }^{30} \mathrm{~N}_{2}$ would be numerically higher than that estimated from ${ }^{15} \mathrm{~N}-\mathrm{N}_{2} \mathrm{O}$, because the ${ }^{29} \mathrm{~N}_{2}$ from anammox represents induced oxidation of ${ }^{14} \mathrm{NH}_{4}{ }^{+}$from the addition of ${ }^{15} \mathrm{NO}_{3}{ }^{-}$, which does not occur in denitrification.

The natural sediment from Alsbäck produced ${ }^{15} \mathrm{~N}-\mathrm{N}_{2} \mathrm{O}$ in the presence of ${ }^{15} \mathrm{NO}_{3}{ }^{-}$(Fig. 2A), which could be used to independently calculate $r_{14}$. On average, $r_{14}$ calculated from ${ }^{15} \mathrm{~N}-\mathrm{N}_{2} \mathrm{O}$ was $0.47 \pm 0.06$ (SEM) and was significantly (paired $t$-test: $\mathrm{p}<0.001$ ) lower than $r_{14}$ calculated from ${ }^{15} \mathrm{~N}-\mathrm{N}_{2}(1.21 \pm 0.22)$. As the site has significant anammox activity (Engström 2004, Engström et al. 2005), this finding agrees well with the expectations outlined above. The correction term $r_{14}$
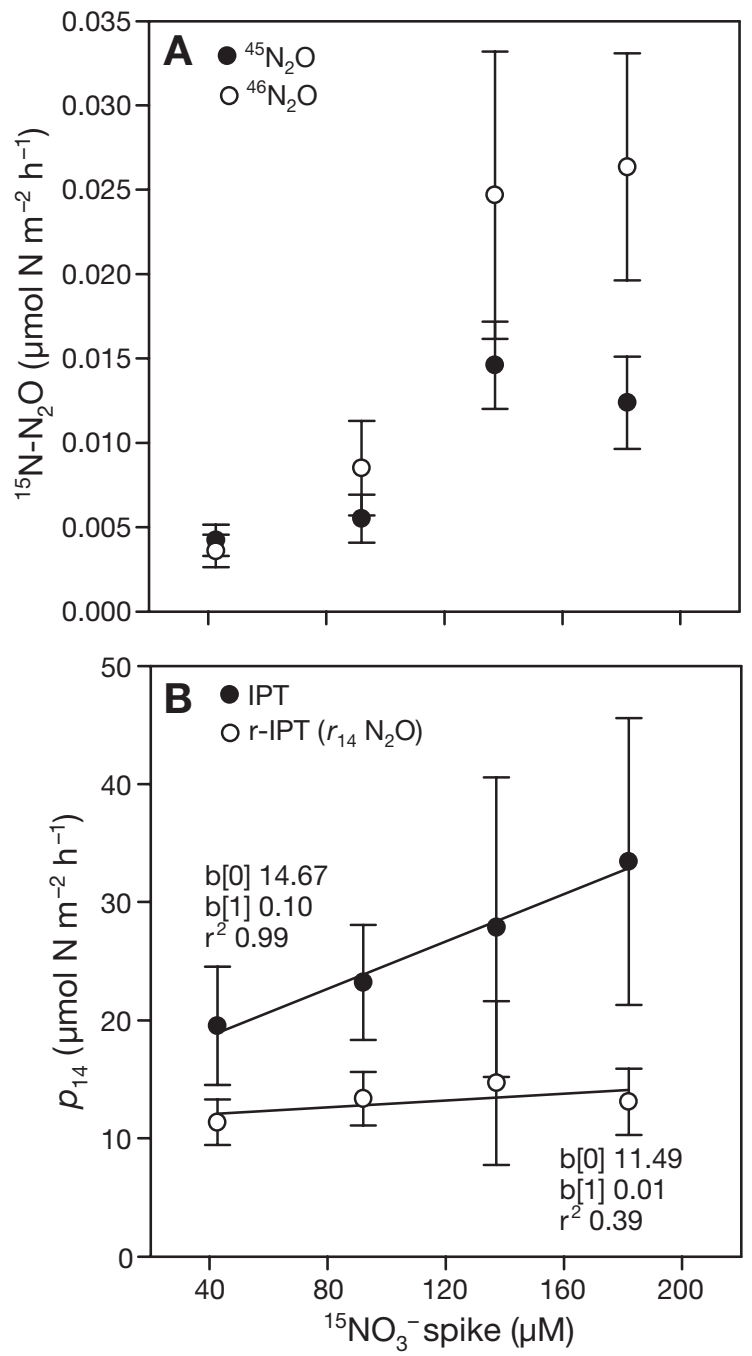

Fig. 2. Use of ${ }^{15} \mathrm{~N}-\mathrm{N}_{2} \mathrm{O}$ to derive direct measure of $r_{14}$ for use in Method 3 in natural sediment from Alsbäck, Sweden. (A) Production of ${ }^{15} \mathrm{~N}-\mathrm{N}_{2} \mathrm{O}$ as a function of ${ }^{15} \mathrm{NO}_{3}{ }^{-}$addition; (B) estimates of true production of $\mathrm{N}_{2}$ gas $\left(p_{14}\right)$ as a function of ${ }^{15} \mathrm{NO}_{3}{ }^{-}$addition using original IPT and r-IPT corrected using Method 3. Values are means \pm 1 SEM $(n=5)$; regression constants: $b[0]=$ intercept,$b[1]=$ slope 
from ${ }^{15} \mathrm{~N}-\mathrm{N}_{2} \mathrm{O}$ was calculated using Eq. (8) for each individual core and used as input to Eq. (2). This produced near constant values for $p_{14}$ that were virtually independent from the ${ }^{15} \mathrm{NO}_{3}{ }^{-}$added (Fig. 2B). Furthermore the estimate of $p_{14}(12.72 \pm 1.47$ (SEM) $\mu$ mol N $\left.\mathrm{m}^{-2} \mathrm{~h}^{-1}\right)$ was $50 \%$ lower $(\mathrm{p}<0.001)$ than the estimate obtained with the classical IPT $(26.01 \pm 4.50$ (SEM) umol $\mathrm{N} \mathrm{m}^{-2} \mathrm{~h}^{-1}$ ) (Table 1). Importantly, Method 3 corrects the IPT even in the natural and heavily bioturbated sediments of Alsbäck and reduces the variation around the estimate of $p_{14}$. This is primarily due to the fact that each measure of $r_{14}$ is derived directly from ${ }^{15} \mathrm{~N}$ gas production in each core, whereas the indirect estimate (Method 1) is based on the assumption that ra is constant for all cores, irrespective of clear heterogeneity (ra estimated in individual cores using the $\mathrm{N}_{2} \mathrm{O}$ method ranged from 30 to $76 \%$ ). Of the average $p_{14}$ of $12.72 \mu \mathrm{mol} \mathrm{N} \mathrm{m}^{-2} \mathrm{~h}^{-1}$, anammox and de-

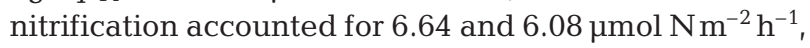
respectively, although average ra from all cores was $48 \%$ (Table 1).

Anammox apparently contributed more to $\mathrm{N}_{2}$ production in intact cores relative to the slurry experiments. With the combination of Methods 1 and 2 in the first Alsbäck experiment, with sieved sediment, anammox accounted for $59 \%$ of $\mathrm{N}_{2}$ production in intact sediment compared to $42 \%$ in slurries, and, with Method 3, 48\% for intact natural sediment compared to $36 \%$ in slurries. This is an important finding and highlights the need for a technique to measure anammox and denitrification in intact sediment cores. Recently published estimates of r-IPT $p_{14}$ in intact cores relied upon Method 1 and the generation of ra from slurries to correct for anammox (RisgaardPetersen et al. 2004a, Rysgaard et al. 2004). In most cases these estimates of $p_{14}$ showed that there was no significant difference between the original IPT $p_{14}$ and r-IPT $p_{14}$ using $r a_{\text {; }}$ however, it is likely that these were underestimates of $r a$ and therefore $p_{14}$ was not sufficiently corrected. The slurry-based method for measuring ra integrates the activity of denitrifiers and anammox bacteria in a volume of sediment and the facultative denitrifiers are, therefore, likely to be overrepresented in anaerobic slurries prepared from mixed aerobic and anaerobic strata. In contrast, this distribution will be more accurately captured by whole-core incubations. In addition, in slurries enriched with $100 \mathrm{\mu M} \mathrm{NO}_{3}{ }^{-}$, transient concentrations of $\mathrm{NO}_{2}^{-}$can be generated, which may exceed the optimal $\mathrm{NO}_{2}{ }^{-}$concentration for anammox (Trimmer et al. 2005).

\section{Time series experiment in the Thames estuary}

The production of ${ }^{15} \mathrm{~N}$-labelled $\mathrm{N}_{2}$ and $\mathrm{N}_{2} \mathrm{O}$ was linear throughout the $6 \mathrm{~h}$ incubation at Southend (Fig. 3A, B) and, importantly, the parameter $r_{14}$ (derived from the ${ }^{15} \mathrm{~N}$ distribution in the labelled $\mathrm{N}_{2} \mathrm{O}$ ) was constant with time in these sediments (Fig. $3 \mathrm{C}: \mathrm{r}^{2}=0.08$, $\mathrm{p}=0.214) \cdot p_{14}$ was calculated using both the original IPT expression (Eq. 1) and r-IPT (Eq. 2) and there was very good agreement between these 2 estimates for $p_{14}$ (Fig. 3D), with no significant difference between either the intercepts $(b[0]: \mathrm{p}=0.706)$ or slopes $(b[1]: \mathrm{p}=0.983)$ (ANCOVA). Under these conditions the application of Nielsen's classic IPT to estimate $p_{14}$ is still perfectly valid and, as there is only a negligible contribution to $\mathrm{N}_{2}$ production from anammox at this site, this is what we expected. In addition, this experiment confirms that denitrification is the only source of ${ }^{15} \mathrm{~N}-\mathrm{N}_{2} \mathrm{O}$ production in these estuarine sediments because, if this were not the case, the r-IPT-estimate would deviate from that of the classic IPT, which was clearly not the case (Fig. 3D).

Table 1. Estimates (means $\pm 1 \mathrm{SEM}$ ) of true $\mathrm{N}_{2}$ production $p_{14 i}\left(\mu \mathrm{mol} \mathrm{N} \mathrm{m}{ }^{-2} \mathrm{~h}^{-1}\right)$ from ${ }^{15} \mathrm{NO}_{3}{ }^{-}$concentration series experiments in

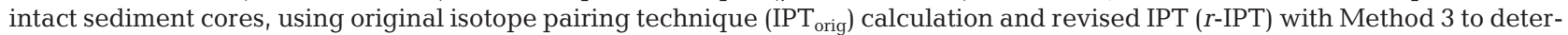
mine $r_{14}$ (ratio of ${ }^{14} \mathrm{NO}_{3}{ }^{-}$to ${ }^{15} \mathrm{NO}_{3}{ }^{-}$in $\mathrm{NO}_{3}{ }^{-}$reduction zone). ra: contribution of anammox to $\mathrm{N}_{2}$ production; na: not applicable; Note: mean $p_{14}$ from Alsbäck has been calculated across all concentrations, despite the dependency of $p_{14}$ on ${ }^{15} \mathrm{NO}_{3}{ }^{-}$, as this represents what would be taken as the mean were the IPT to be applied in its original form

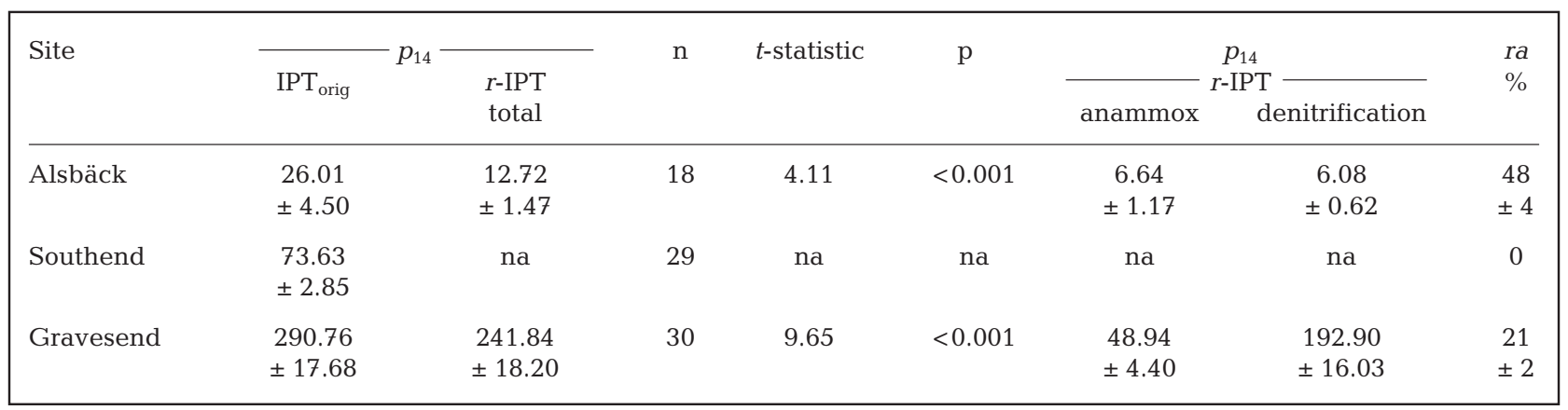



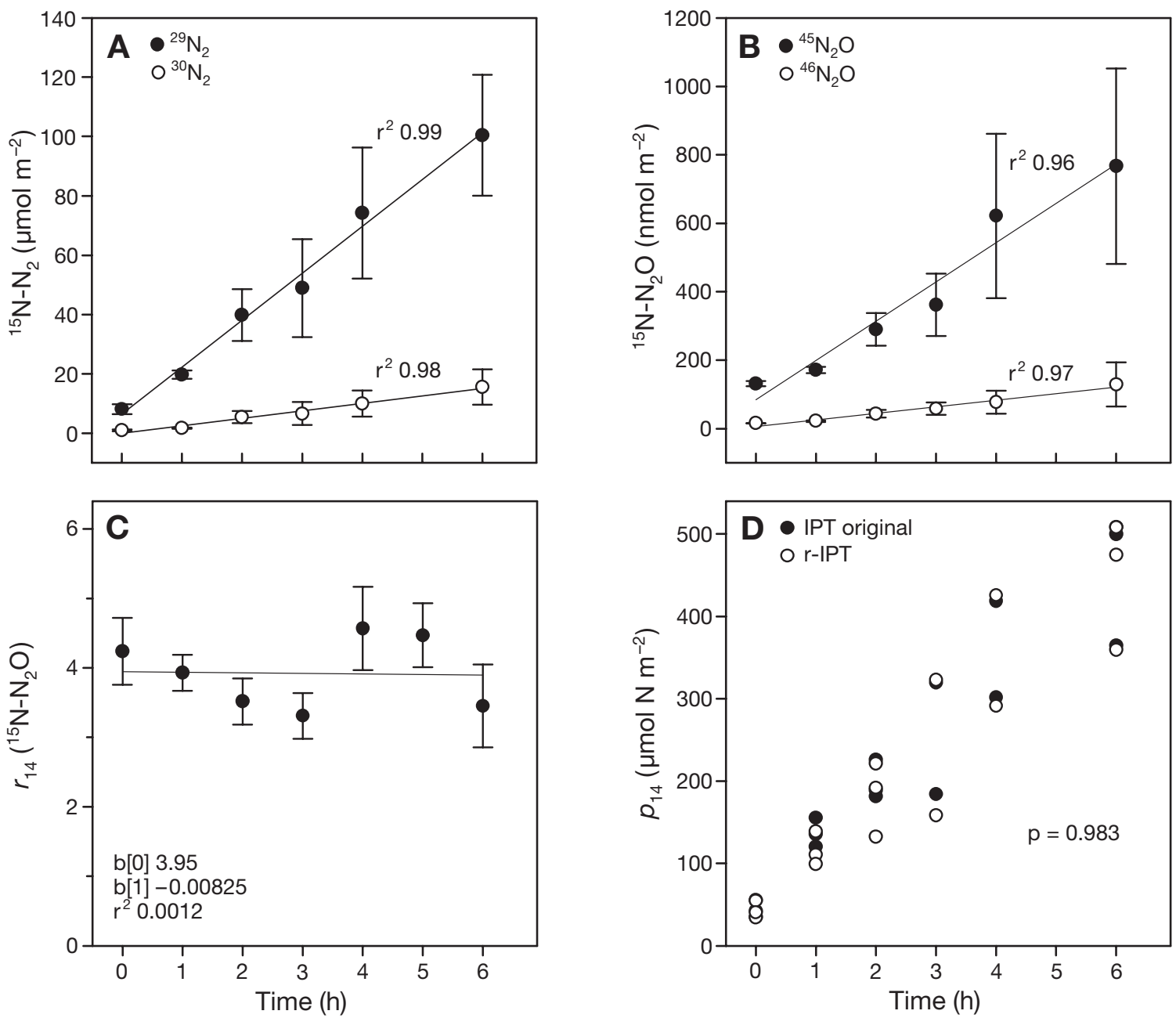

Fig. 3. Time series incubations for sediment with minimal anammox activity from Southend in the Thames estuary. (A, B) Production of ${ }^{29} \mathrm{~N}_{2}$ and ${ }^{30} \mathrm{~N}_{2}$ and ${ }^{45} \mathrm{~N}_{2} \mathrm{O}$ and ${ }^{46} \mathrm{~N}_{2} \mathrm{O}$ as a function of time, respectively; (C) $r_{14}$ derived from ${ }^{15} \mathrm{~N}$ labelling of $\mathrm{N}_{2} \mathrm{O}$ as a function of time; (D) estimates of true production of $\mathrm{N}_{2}$ gas $\left(p_{14}\right)$ as a function of time using original IPT and the r-IPT corrected using Method 3. Values are means \pm 1 SEM $(n=4)$; regression constants: $b[0]=$ intercept, $b[1]=$ slope

\section{Concentration series experiments in the Thames estuary}

The results for Alsbäck showed that a direct measure of $r_{14}$ from ${ }^{15} \mathrm{~N}-\mathrm{N}_{2} \mathrm{O}$ using the r-IPT could remove the dependency between $p_{14}$ and ${ }^{15} \mathrm{NO}_{3}{ }^{-}$, and we wanted to show that this held where anammox was less significant. Although there was a significant correlation between the production of ${ }^{15} \mathrm{~N}-\mathrm{N}_{2}$ gas at both Southend and Gravesend with ${ }^{15} \mathrm{NO}_{3}{ }^{-}$concentration $\left(\mathrm{r}^{2}=0.58\right.$ $\mathrm{p}<0.001, \mathrm{r}^{2}=0.50 \mathrm{p}<0.001$, respectively), as would be expected, there was no such relationship with ${ }^{15} \mathrm{~N}-\mathrm{N}_{2} \mathrm{O}$ production. Given that $\mathrm{N}_{2} \mathrm{O}$ is an intermediate in the denitrification pathway and that it is, in turn, metabolised to $\mathrm{N}_{2}$, such a correlation between ${ }^{15} \mathrm{~N}-\mathrm{N}_{2} \mathrm{O}$ production and ${ }^{15} \mathrm{NO}_{3}{ }^{-}$addition need not be expected in the more reactive sediments of the Thames estuary. The power of this approach (Method 3) lies in the abili- ty to discern a difference between the distribution of ${ }^{15} \mathrm{~N}$ in both the $\mathrm{N}_{2}$ and $\mathrm{N}_{2} \mathrm{O}$ pools, and the actual pattern of production is irrelevant. Using the parameter $q$ and by rearrangement of Eq.(10) it is possible to predict the expected deviation from 1 in the slope $q \mathrm{~N}_{2}$ vs. $q \mathrm{~N}_{2} \mathrm{O}$ at any ra. The expected slopes for a range of $r a$ $($ ra $\%=0,25,50,75)$ are shown in Fig. 4A. Previous estimates of the contribution of anammox from slurry incubations at Southend and Gravesend were $<1$ and $5 \%$, respectively (Trimmer et al. 2003). The $q \mathrm{~N}_{2}$ vs. $q$ $\mathrm{N}_{2} \mathrm{O}$ plots of the data from Southend and Gravesend, together with the expected $q \mathrm{~N}_{2}$ vs. $q \mathrm{~N}_{2} \mathrm{O}$ plots from the slurry estimate of ra are shown in Fig. $4 \mathrm{~B}$ and $\mathrm{C}$, respectively. At Southend, the slope is not significantly different from $1(b[1]=1.05 \pm 0.10(95 \% \mathrm{CI}), \mathrm{df}=28$, $t=1.81, \mathrm{p}>0.05)$, there is no difference in the distribution of ${ }^{15} \mathrm{~N}$ in the two ${ }^{15} \mathrm{~N}$ gas species, and $p_{14}$ using the 

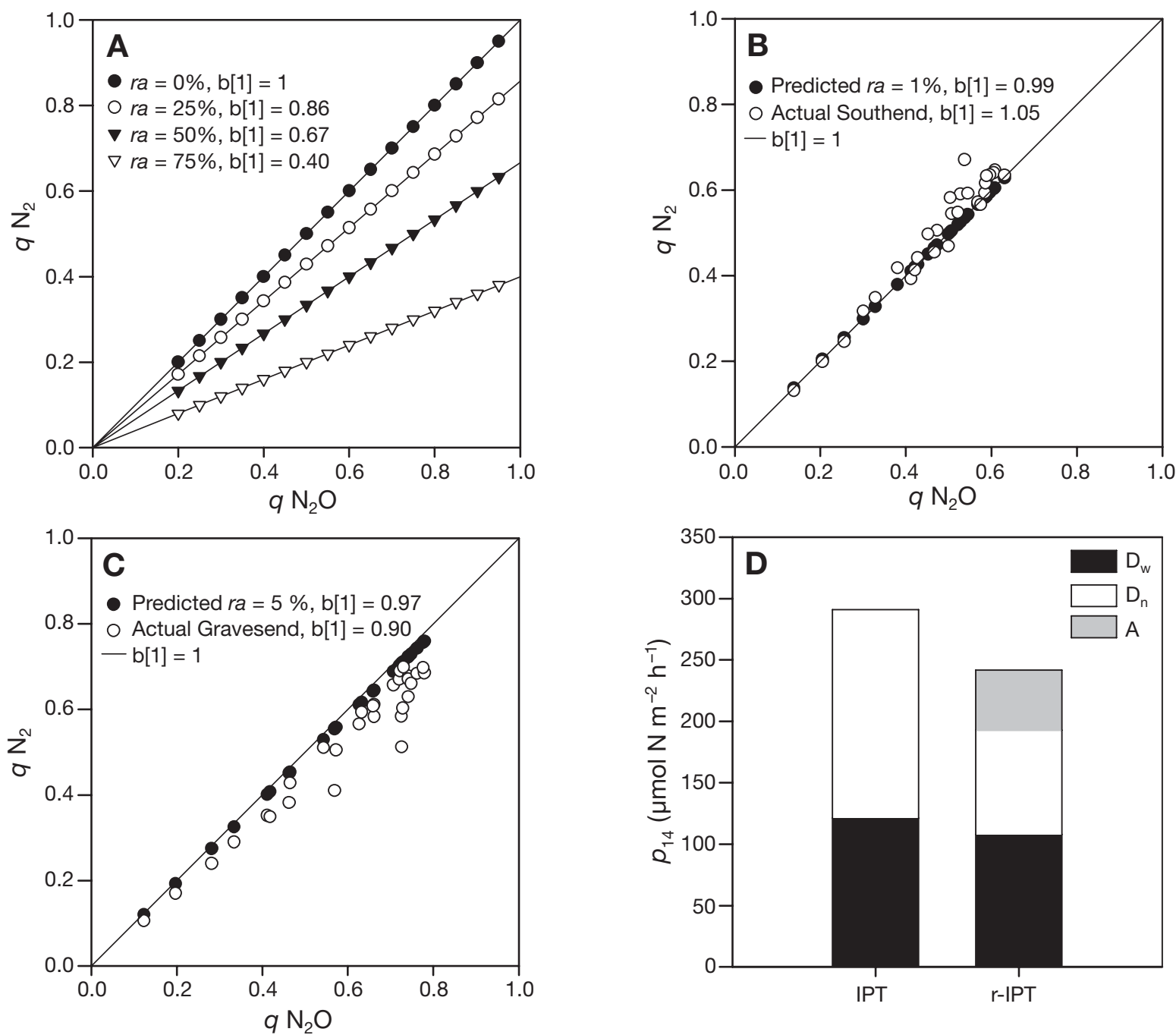

Fig. 4. Concentration series incubations for sediment with minimal and low anammox activity from the Thames estuary. (A) Theoretical deviations in $q \mathrm{~N}_{2}$ vs. $q \mathrm{~N}_{2} \mathrm{O}$ slope (b[1]) with changing $r a_{\text {; }}$ (B) scatter of $q \mathrm{~N}_{2}$ vs. $q \mathrm{~N}_{2} \mathrm{O}$ at Southend as predicted with ra from slurries, actual data and $b[1]=1$ for comparison; (C) scatter of $q \mathrm{~N}_{2}$ vs. $q \mathrm{~N}_{2} \mathrm{O}$ at Gravesend as predicted with ra from slurries, actual data and $b[1]=1$ for comparison; (D) estimates of true production of $\mathrm{N}_{2}$ gas $\left(p_{14}\right)$ at Gravesend and subsequent distribution into $\mathrm{D}_{\mathrm{w}}, \mathrm{D}_{\mathrm{n}}$ and anammox, using original IPT and r-IPT corrected with Method 3

original IPT was, on average, $73.63 \pm 2.85$ (SEM) $\mu \mathrm{mol}$ $\mathrm{N} \mathrm{m}^{-2} \mathrm{~h}^{-1}$ (Table 1).

In contrast, at Gravesend, where anammox has been shown to be significant, the slope of the 2 derivations of $q$ was significantly different from $1(b[1]=0.90 \pm 0.09$ $(95 \% \mathrm{CI}), \mathrm{df}=29, t=2.43, \mathrm{p}<0.05)$ and, more importantly, significantly different from the data at Southend ( $<<0.001$, ANCOVA). Unlike Alsbäck (Fig. 1), however, there was no significant dependency between $p_{14}$ and ${ }^{15} \mathrm{NO}_{3}{ }^{-}(b[1]: \mathrm{p}>0.05)$. As previously discussed, in an estuarine environment, where $r_{14}$ is high and $r a$ is low, this deviation is unlikely to be visibly apparent (Risgaard-Petersen et al. 2003). However, using Method 3 , the estimate for $p_{14}$ with the r-IPT of 241.84 \pm 18.20 (SEM) is significantly lower than the original
IPT $p_{14}$ estimate of $290.76 \pm 17.68$ (SEM) (paired $t$ test, $\mathrm{p}<0.001$ ) (Table 1) and, hence, the production of false ${ }^{29} \mathrm{~N}_{2}$ from anammox is enough to cause the original IPT to overestimate $p_{14}$. The percentage contribution of anammox to $\mathrm{N}_{2}$ production in intact sediment was calculated to be $21.36 \pm 1.65$ (SEM), which is greater than the previous estimate from slurries of $5 \%$.

In the presence of anammox, an additional problem with the original IPT, apart from overestimating $p_{14}$ and not accounting for anammox, is that of overestimation of coupled nitrification-denitrification $\left(D_{n}\right)$, since part of the 'false' ${ }^{29} \mathrm{~N}_{2}$ could be interpreted as $\mathrm{D}_{\mathrm{n}}$ rather than anammox. As stated above, however, this excess ${ }^{29} \mathrm{~N}_{2}$ represents neither true anammox nor denitrification. The distributions of $p_{14}$ as $\mathrm{D}_{\mathrm{n}}, \mathrm{D}_{\mathrm{w}}$ and anammox 
from Gravesend, calculated using the equations of Nielsen (1992) with and without the IPT revision, are shown in Fig. 4D. On average, the original IPT calculation overestimated $D_{n}$ by $100 \%$, clearly illustrating the significance of the problem.

Clearly the robustness of our $r_{14}{ }^{15} \mathrm{~N}-\mathrm{N}_{2} \mathrm{O}$ technique (Method 3) hinges on denitrification being the only significant source of ${ }^{15} \mathrm{~N}-\mathrm{N}_{2} \mathrm{O}$ from ${ }^{15} \mathrm{NO}_{3}{ }^{-}$, and we have argued that the good agreement between the estimates for $p_{14}$ with either the r-IPT or the original IPT at Southend supports this (Fig. 3D). In principle, however, isotopic discrimination during denitrification could violate our central assumption. Middelburg et al. (1996) dealt with the potential impact of ${ }^{15} \mathrm{~N}$ discrimination during the application of the IPT technique and showed that it would affect the results at most by $<0.5 \%$, with a discrimination factor of $40 \%$. Our situation is slightly different from this, since we are using differences in the distribution of ${ }^{15} \mathrm{~N}$ in the ${ }^{15} \mathrm{~N}-\mathrm{N}_{2}$ pool and ${ }^{15} \mathrm{~N}-\mathrm{N}_{2} \mathrm{O}$ pool to discern an effect of anammox on this distribution and, in theory, this difference could be affected by isotopic fractionation. On average, the fractionation between $\mathrm{NO}_{3}{ }^{-}$and $\mathrm{N}_{2}$ is $24 \%$ and therefore, between $\mathrm{N}_{2} \mathrm{O}$ and $\mathrm{N}_{2}$, it is approximately 12 to $13 \%$ (Barford et al. 1999). A simple comparison between this magnitude of fractionation $(12 \%$, i.e. 0.012 ) and the confidence intervals (90\%, i.e. 0.090) for $q \mathrm{~N}_{2}$ vs. $q \mathrm{~N}_{2} \mathrm{O}$ for the data from Southend and Gravesend shows that any effect from fractionation is unlikely to be discernible in our estimates of $r_{14}$. It could also be argued that $\mathrm{N}_{2} \mathrm{O}$ production during nitrification could affect our estimate of $r_{14}$. Shaw et al. (2006) showed that Nitrosospira spp. produced $\mathrm{N}_{2} \mathrm{O}$ under aerobic conditions and that $50 \%$ of the resultant ${ }^{15} \mathrm{~N}-\mathrm{N}_{2} \mathrm{O}$ must have come from a coupling between ${ }^{15} \mathrm{NO}_{2}{ }^{-}$and ${ }^{14} \mathrm{NH}_{4}{ }^{+}$, although it represented $\sim 0.2 \%$ of the net $\mathrm{NO}_{2}{ }^{-}$production. If this were happening to any appreciable degree in our sediments, then nitrification-based ${ }^{15} \mathrm{~N}-\mathrm{N}_{2} \mathrm{O}$ production would increase $r_{14}\left(\mathrm{~N}_{2} \mathrm{O}\right)$ and $r_{14} \mathrm{~N}_{2} \mathrm{O}$ would exceed $r_{14}$ 'true', i.e. our estimate of the ratio between ${ }^{14} \mathrm{NO}_{3}{ }^{-}$to ${ }^{15} \mathrm{NO}_{3}{ }^{-}$in the $\mathrm{NO}_{3}{ }^{-}$reduction zone would be wrong. We know that nitrification is significant at Southend, with $50 \%$ of denitrification being fuelled by nitrification, i.e. $D_{n}$ (Trimmer et al. 2000), and it is implicit in Fig. 3C (i.e. $r_{14}$ $\left[\mathrm{N}_{2}\right.$ or $\left.\mathrm{N}_{2} \mathrm{O}\right]$ equals 3.95 with only $30 \%{ }^{15} \mathrm{~N}$ in the overlying water). Even with $50 \%$ of the ${ }^{29} \mathrm{~N}_{2}$ production (Fig. 3A) coming from $\mathrm{D}_{\mathrm{n}}$, and $0.2 \%$ of this yielding ${ }^{45} \mathrm{~N}_{2} \mathrm{O}$, this could only explain about $14 \%$ of the measured amount of ${ }^{45} \mathrm{~N}_{2} \mathrm{O}$ (Fig. 3B). Quite simply, however, the data in Fig. 3D show that any effect from nitrification is minimal; otherwise the 2 estimates of $p_{14}$ would deviate from each other, which they do not. In addition, any overestimate of $r_{14}$, i.e. $r_{14} \mathrm{~N}_{2} \mathrm{O}>r_{14}$ true, would underestimate anammox (ra) and anaerobic slurry incubations would give higher estimates for ra than those in intact cores; yet we see the opposite trend, despite the fact that nitrification is relatively high at both Gravesend (Fig. 4D) and Alsbäck (where pore water $\mathrm{NO}_{3}{ }^{-} \geq$water column $\mathrm{NO}_{3}{ }^{-}$). Hence, aerobic production of ${ }^{15} \mathrm{~N}_{2} \mathrm{O}$ from ${ }^{15} \mathrm{NO}_{2}{ }^{-}$can be ignored in practice.

The production of $\mathrm{N}_{2} \mathrm{O}$ during $\mathrm{NO}_{3}{ }^{-}$or $\mathrm{NO}_{2}{ }^{-}$reduction to ammonium (DNRA) has also been reported in pure culture (Smith \& Zimmerman 1981, Smith 1982). However, $\mathrm{N}_{2} \mathrm{O}$ production dropped by $90 \%$ when $\mathrm{NO}_{2}{ }^{-}$ changed from 15000 to $150 \mu \mathrm{M}$ in these pure culture experiments, and the highest $\mathrm{NO}_{2}^{-}$concentration we have ever measured in sediments is $16 \mu \mathrm{M}$. We suggest, therefore, that this process is negligible. Further, ${ }^{15} \mathrm{~N}$ gas can account for $100 \%$ of the ${ }^{15} \mathrm{NO}_{3}{ }^{-}$reduced in our slurry incubations (Trimmer et al. 2003), showing that DNRA is insignificant in the sediment studied here. Obviously, $\mathrm{N}_{2} \mathrm{O}$ production via anammox would weaken our case and it would underestimate anammox with Method 3, although (according to present knowledge) anammox does not produce $\mathrm{N}_{2} \mathrm{O}$ or, if it does, only in trace amounts (i.e. $<0.01 \%$ of the anammox rate) that may be due to $\mathrm{NO}_{2}{ }^{-}$toxicity at high concentrations (van de Graaf et al. 1997, Strous et al. 1998).

\section{CONCLUSION}

In the present study we have explored the limits of a methodology for measuring anammox and denitrification in intact cores proposed in a previous study (Risgaard-Petersen et al. 2003), and our findings with data for sediments with contrasting anammox activity fully support the theoretical proposals for correcting the IPT. However, the methodology originally proposed by Risgaard-Petersen et al. (2003) for quantifying the central input parameter $r_{14}$ based on Method 2 ( $V$ ), although effective, has obvious limitations. The derivation of the parameter ra and, in turn, $r_{14}$ (Method 1) from sediment slurry incubations has been shown not to be applicable to intact sediment cores, since it significantly underestimates the contribution from anammox to $\mathrm{N}_{2}$ production and, therefore, cannot correct the IPT. Previous estimates of $p_{14}$ using ra from slurries (Risgaard-Petersen et al. 2004a, Rysgaard et al. 2004) are likely to have been overestimates, and therefore, this study represents the first true measurements of $p_{14}$ from intact sediment cores where anammox and denitrification coexist. The ${ }^{15} \mathrm{~N}-\mathrm{N}_{2} \mathrm{O}$-based methodology presented here represents a much more rigorous approach, as it enables direct measurements of $r_{14}$ in individual cores. This technique, in combination with the general revised procedure for calculation of true $\mathrm{N}_{2}$ production ( $p_{14}$ : Eq. 2 ), allows denitrification (and sub- 
sequently $D_{n}$ and $D_{w}$ ) and anammox to be quantified in intact sediments using similar techniques to those already established with the original IPT.

Acknowledgements. We thank the support staff at the Kristineberg Marine Field station, Sweden. S. Hulth, T. Dalsgaard and K. Sundbäck are thanked for fruitful discussions about the experimental design. This research was funded in part by a Research Grant (NER/A/S/2003/00354) to M.T. by the Natural Environment Research Council, UK, and in part by the Danish Natural Science Research Council and the Carlsberg Foundation, Denmark, to N.R-P. P.E. was funded by the Foundation for Strategic Environmental Research, Sweden (MISTRA).

\section{LITERATURE CITED}

Barford CC, Montoya JP, Altabet MA, Mitchell R (1999) Steady-state nitrogen isotope effects of $\mathrm{N}_{2}$ and $\mathrm{N}_{2} \mathrm{O}$ production in Paracoccus denitrificans. Appl Environ Microbiol 65:989-994

Dalsgaard T, Thamdrup B (2002) Factors controlling anaerobic ammonium oxidation with nitrite in marine sediments. Appl Environ Microbiol 68:3802-3808

Dalsgaard T, Nielsen LP, Brotas V, Viaroli P \& 10 others (2000) Protocol handbook for NICE - nitrogen cycling in estuaries: a project under the EU research programme: Marine Science and Technology (MAST III), National Environmental Research Institute, Silkkeborg

Dalsgaard T, Thamdrup B, Canfield DE (2005) Anaerobic ammonium oxidation (anammox) in the marine environment. Res Microbiol 156:457-464

Engström P (2004) The importance of anaerobic ammonium oxidation (anammox) and anoxic nitrification for $\mathrm{N}$ removal in coastal marine sediments. PhD, Göteborg University

Engström P, Dalsgaard T, Hulth S, Aller RC (2005) Anaerobic ammonium oxidation by nitrite (anammox): implications for $\mathrm{N}_{2}$ production in coastal marine sediments. Geochim Cosmochim Acta 69:2057-2065

Middelburg JJ, Soetaert K, Herman PMJ (1996) Evaluation of the nitrogen isopairing technique for measuring benthic denitrification: a simulation analysis. Limnol Oceanogr 41: 1833-1839

Nielsen LP (1992) Denitrification in sediments determined from nitrogen isotope pairing. FEMS Microbiol Ecol 86: 357-362

Risgaard-Petersen N, Rysgaard S (1995) Nitrate reduction in sediments and waterlogged soils measured by ${ }^{15} \mathrm{~N}$ techniques. In: Alef K, Nannipieri P (eds) Methods in applied soil microbiology. Academic Press, London, p 287-296

Risgaard-Petersen N, Nielsen LP, Rysgaard S, Dalsgaard T,

Editorial responsibility: Otto Kinne (Editor-in-Chief), Oldendorf/Luhe, Germany
Meyer RL (2003) Application of the isotope pairing technique in sediments where anammox and denitrification coexist. Limnol Oceanogr Meth 1:63-73

Risgaard-Petersen N, Meyer RL, Schmid M, Jetten MSM, Enrich-Prast A, Rysgaard S, Revsbech NP (2004a) Anaerobic ammonium oxidation in an estuarine sediment. Aquat Microb Ecol 36:293-304

Risgaard-Petersen N, Nielsen LP, Rysgaard S, Dalsgaard T, Meyer RL (2004b) Application of the isotope pairing technique in sediments where anammox and denitrification coexist. Limnol Oceanogr Meth 2:315-315

Rysgaard S, Glud RN, Risgaard-Petersen N, Dalsgaard T (2004) Denitrification and anammox activity in Arctic marine sediments. Limnol Oceanogr 49:1493-1502

Shaw LJ, Nicol GW, Smith Z, Fear J, Prosser JI, Baggs EM (2006) Nitrosospira spp. can produce nitrous oxide via a nitrifier denitrification pathway. Environ Microbiol 8:214222

Smith MS (1982) Dissimilatory reduction of $\mathrm{NO}_{2}^{-}$to $\mathrm{NH}_{4}{ }^{+}$and $\mathrm{N}_{2} \mathrm{O}$ by a soil Citrobacter sp. Appl Environ Microbiol 43: $854-860$

Smith MS, Zimmerman K (1981) Nitrous-oxide production by non-denitrifying soil nitrate reducers. Soil Sci Soc Am J 45: 865-871

Steingruber SM, Freidrich J, Gächter R, Wehrli B (2001) Measurements of denitrification in sediments with the ${ }^{15} \mathrm{~N}$ isotope pairing technique. Appl Environ Microbiol 67: 3771- 3778

Strous M, Heijnen JJ, Kuenen JG, Jetten MSM (1998) The sequencing batch reactor as a powerful tool for the study of slowly growing anaerobic ammonium-oxidizing microorganisms. Appl Microbiol Biotechnol 50:589-596

Thamdrup B, Dalsgaard T (2002) Production of $\mathrm{N}_{2}$ through anaerobic ammonium oxidation coupled to nitrate reduction in marine sediments. Appl Environ Microbiol 68: $1312-1318$

Trimmer M, Nedwell DB, Sivyer DB, Malcolm SJ (2000) Seasonal benthic organic matter mineralisation measured by oxygen uptake and denitrification along a transect of the inner and outer River Thames estuary, UK. Mar Ecol Prog Ser 197:103-119

Trimmer M, Nicholls JC, Deflandre B (2003) Anarobic ammonium oxidation measured in sediments along the Thames Estuary, United Kingdom. Appl Environ Microbiol 69: 6447-6454

Trimmer M, Nicholls JC, Morley N, Davies CA, Aldridge J (2005) Biphasic behavior of anammox regulated by nitrite and nitrate in an estuarine sediment. Appl Environ Microbiol 71:1923-1930

van de Graaf AA, de Bruijn P, Robertson LA, Jetten MSM, Kuehn JG (1997) Metabolic pathway of anaerobic ammonium oxidation on the basis of ${ }^{15} \mathrm{~N}$ studies in a fluidized bed reactor. Microbiol UK, 141:2415-2421

Submitted: January 19, 2006; Accepted: March 29, 2006

Proofs received from author(s): October 9, 2006 